\title{
Against Romanticism
}

\author{
SAM SHPALL \\ University of Sydney
}

A maid sat captive in a stone tower. She loved a lord. Why? Ask the wind and the stars, ask the God of Life; for none other knows these things. And the lord was her friend and her lover; but time passed and one fine day he saw another, and his feelings changed.

-Knut Hamsun, Pan

$\mathrm{T}$ HE romanticism of my title is a family of views about love's relationship to reasons. What unites these views is the idea that love is immunised from assessments of reasonableness and appropriateness. As we'll see, philosophers express romantic ideologies in a variety of non-identical formulations, and routinely slide between normative and descriptive claims. But the characteristic romantic thought is a normative one: love is an outlier in moral psychology in virtue of its relationship to justification. Love's insulation from reasons, it is said, accounts for much of its puzzling nature, and appreciating this is the source of important insights about the human condition. ${ }^{1}$

Like many philosophers, I find romantic views implausible. Nonetheless, understanding what motivates romanticism is important, in part because of its connections to widespread patterns of thinking, behaviour, and social practice. This essay engages in an extended reconstruction and critique of possible motivations for romantic ideas. Besides giving this interesting family of views its due, my critique sheds light on various sources of confusion in our thinking about

1. There are terminological subtleties here. It is widely agreed that the locus of the debate between romantics and their opponents is a set of theses about whether there are reasons for love. I think these theses can be helpfully cast in several related idioms-employing the language of rationality, appropriateness, fittingness, and justification (compare Abramson and Leite 2018). Some are less comfortable applying one or other of these idioms. None of my arguments turn on contentious theses about their relations.

Contact: Sam Shpall <sam.shpall@sydney.edu.au> 
love, concerning topics that are of interest to philosophers and non-philosophers alike.

I begin with some examples of the notions that interest me. Consider first a classic passage from the speech of Pausanias in the Symposium:

Suppose, for example, that in order to secure money, or a public post, or any other practical benefit ... a man were willing to do what lovers do.... His enemies would jeer at his fawning servility, while his friends, ashamed on his behalf, would try everything to bring him back to his senses. But let a lover act in any of these ways, and everyone will immediately say what a charming man he is! (Symposium $183 \mathrm{a}-\mathrm{b})^{2}$

As Pausanias observes, behaviour that is normally judged unreasonable and shameful is often excused, or even valorised, when it is seen to issue from love. The tendency to excuse love-conduct otherwise unbecoming is related to the tendency to dismiss the legitimacy of evaluating it-and the love that motivates it-altogether.

The source of this first passage demonstrates romanticism's historical pedigree. Intellectual and cultural vitality is one reason for finding such views interesting. Their practical dangers are another. Here is a much more recent piece of narration:

I was not morally appalled by what my father was setting out to do. Mitru's suicide and my father's madness had convinced me that sexual love was a passion whose force and nature was mysterious, and that anyone who came under its sway should be prepared to be destroyed by it. . . The requirement to consent to such possibilities seemed to me to be intrinsic to love's nature and, therefore, inseparable from its joys. ... For me it was never a question of justification. I simply refused to condemn my father for intending to shoot Lydia's husband. (Gaita 1998: 137-138)

The description is frighteningly insightful. Romantic love is both the intellectual foundation of romanticism and the site of its grisliest practical consequences. Again, if love is beyond justification, then it can seem as if acting from love is as well. ${ }^{3}$

The cluster of beliefs I'm calling romanticism is pervasive. Its strands and roots are hard to disentangle. Harry Frankfurt (2004) gives the most prominent

2. Plato (1997: 467).

3. See the compelling discussion at Jenkins (2017: 115). I'm not claiming that refusal to condemn the acts of lovers is required if we think that love itself is beyond justification. I'm claiming that regarding love as beyond justification is associated with refusal to condemn certain acts. 
defence of romantic views in the philosophical literature. ${ }^{4}$ Academic writing like Frankfurt's is clearly only one small contributor to romanticism's persistence. Yet the intellectual and social import of romantic views makes their sustained investigation by philosophers especially worthwhile.

After introducing and situating several romantic theses about love, I discuss three general argumentative strategies for motivating them. Some have been more influential in contemporary philosophy than others. Jointly they exhaust the most common underlying justifications offered in the philosophical literature as well as in ordinary thought. I highlight several characteristic weaknesses in these arguments that have not been adequately appreciated. In doing so, I frame various positive theses about the distinctiveness of love's connection to reason.

I conclude this introduction with a methodological note. Romantic views about love's rational status are my main target. But throughout I will also be drawing attention to another tendency: the romanticising of our discourse about love. Philosophers devote much more intellectual energy to the phenomenon of romantic love than to other forms of personal love. ${ }^{5}$ In this they are like artists, and indeed most people. The emphasis shapes our ideas in subterranean ways. ${ }^{6}$ My observations about the romanticising of our discourse will help to underline some of the problems with romantic views, and I hope they will be independently stimulating. This explains my choice of the term "romanticism," which makes the connection between the two romantic threads explicit.

\section{Romanticism in Contemporary Philosophy}

I've mentioned that Harry Frankfurt (1999; 2004) is the most prominent contemporary philosopher to endorse a romantic (or "no reasons"7) view about love. There are many subtleties in interpreting him.

Consider this well-known claim (Frankfurt 2004: 55-56): "Love is the origi-

4. For discussion of affinities between Frankfurt's views and Singer's (1966) "bestowal" account see Helm (2017).

5. I leave cases of love for non-persons to the side, though I think such cases are important. See Shpall (2017; 2018).

6. Sometimes the focus on romantic love is explicit. See de Sousa (2015), Brogaard (2015), and Jenkins (2017). In other cases, it is not sufficiently explicit-as will become clear later on. Philosophy about romantic love is great, just as philosophy about parental love (e.g., Liao 2015) and friendship (e.g., Nehamas 2016) is great. My contention is that romantic love is the intellectual hub of many profoundly influential yet misguided assumptions. Compare Brake (2012: 5): "the assumption that the most valuable relationships must be marital or amorous devalues friendships ... marriage and the associated pressures of amatonormativity can threaten care."

7. It would be better to refer to this as the "no antecedent reasons" view. This is an additional justification for my terminology. 
nating source of terminal value . . the ultimate ground of practical rationality." Frankfurt contrasts his view with those that understand love as a (potentially) apt response to worth or value. He insists, with characteristic verve, that his love for his children is not a response to any independent judgments of their worthiness (2004: 39). Frankfurt means not just that his love isn't caused by such judgments. He means to deny that its appropriateness depends on them. ${ }^{8}$ The claim that the appropriateness of love does not depend on the independent value of the beloved, or judgments about that value, is naturally associated with the romantic thesis that love is not the kind of thing that can be appropriate at all. This helps to explain why Frankfurt is commonly taken to be the standard bearer of the romantic position (see Kroeker \& Schaubroeck 2017: xiv; Smuts 2014b).

However, this characterization of Frankfurt as a romantic is not wholly uncontroversial, because he at times appears to accept the aptness of reasonsjudgments about love-for example, the judgment that love can be regrettable. 9 His view, or a nearby one, might dispense with the claim that love is totally beyond the pale of reason. The crux of the position might instead be best understood as a view about the ground of reasons for loving: these reasons are generated exclusively by love itself. ${ }^{10}$

I will show momentarily that romanticism comes in starker varieties. Still, it is worth observing how Frankfurt's view immunizes love from justification. To say that love is the lone source of reasons is to say that practical rationality is completely love-relative. My love for Asghar cannot be unreasonable - at least short of undermining loves that I love more. Awkwardness of formulation notwithstanding, the idea should be recognizable. Love for Frankfurt is akin to underivative desire for Humean theories of practical reason, which hold that underivative desires are not subject to rational assessment-unless, say, such desires conflict. ${ }^{11}$

8. Frankfurt's treatment here could more carefully separate questions about causes of love from questions about reasons for love. Suppose that love is indeed "brought about-in ways that are poorly understood - by a disparate variety of natural causes" (2004: 38). This does little to vindicate any particular thesis about whether love can be rational or appropriate. Similar causal claims apply to (e.g.) migraines and envy, but this does not entail much about their appropriateness conditions. Compare Hurka (2017) and Abramson and Leite (2018).

9. See Frankfurt (2004: 39, my italics): "If my children should turn out to be ferociously wicked ... I might perhaps recognize that my love for them was regrettable. But I suspect that ... I would continue to love them anyway." Perhaps Frankfurt means only that the love would be regrettable because it would promote evil, and denies that this amounts to the relevant kind of reasons-judgment.

10. Frankfurt (2004: 38): "It is true that the beloved invariably is, indeed, valuable to the lover. However, perceiving that value is not at all an indispensable formative or grounding condition of the love.... The truly essential relationship between love and the value of the beloved goes in the opposite direction."

11. There is a puzzle concerning what Frankfurt should say about the loveless. We may be tempted to agree (2004: 40; see also Wolf 2010 and Shpall 2018) that love explains much of the 
In any event, at least two philosophers have recently endorsed romantic views in even more striking formulations. According to Nick Zangwill, love is amoral and arational, "and that is its glory" (Zangwill 2013: 313). Zangwill defends two main theses about love and rationality that are worth distinguishing. The first is that love does not contain an evaluation (as fear might contain the evaluation that an object is dangerous). ${ }^{12}$ The second is that love is not governed by evaluations. Both theses arguably present love as an outlier in moral psychology. But it is the second thesis about the inaptness of rational evaluations (i.e., the lack of reasons for love) that will interest us here. ${ }^{13}$

Aaron Smuts (2014a: 95) agrees: love cannot be justified. He means not that all love is unjustified, but rather that all love is neither justified nor unjustified. Love has causes, but not reasons. Questions about love's justification are silly questions. They are like questions about the justification of a bout of vertigo.

I'll offer two preliminary observations about why this position is interesting and radical. First, compare the romanticism of Zangwill and Smuts to the Humean views just invoked. Even the fiercely sceptical Hume of the Treatise thinks that some desires can be irrational. They are irrational in virtue of being based on irrational beliefs. This is sometimes conceived as "merely derivative irrationality" in an attempt to minimise its significance. Hume himself claims, for example, that it is the belief, rather than the desire, that is the real culprit in such circumstances. ${ }^{14}$ But it seems to me that this picture suggests desires are governed in some minimal sense by rational norms. ${ }^{15}$ More to the point, contemporary Humeans about practical reason almost universally endorse some substantive rational constraints on desire. For example, they typically claim that while underivative desires are not rationally evaluable, derivative desires are still to be evaluated on the basis of coherence constraints, such as a requirement to desire the believed necessary means to one's most desired ends.

value and meaningfulness in human lives. But an odd consequence of Frankfurt's claims is that the loveless are condemned to live without any practical reasons whatsoever.

12. This is a main theme of Hamlyn, from which Zangwill takes inspiration, e.g.: "Loving someone or something is not incompatible with, for example, having no respect for them, finding them in many ways distasteful or recognizing in them a whole series of bad qualities which are not overridden by good qualities" (Hamlyn 1978: 16).

13. Zangwill (2013: 309): "We do not love for reasons. Love is not subject to rational requirements. Love has causes but not reasons." The transition from the first sentence to the second, if it is meant to express an evidential connection, exemplifies a common flaw in blindness arguments. See Section 2.

14. Hume (1978: 416): "a passion must be accompany'd with some false judgment, in order to its being unreasonable; and even then 'tis not the passion, properly speaking, which is unreasonable, but the judgment."

15. Compare Hubin on Hume (1991: 27): "my desire to wear a garlic necklace may be irrational if it is based on the irrational belief in vampires ..." If the irrational belief upon which the desire is based gets revised, then the desire had better get revised as well. 
Hume is not commonly thought to be a rationalist about desire, and for good reason! But we have now observed that romantics who believe that starting, continuing, and ending love are never justified or unjustified (Smuts 2014b: 522) endorse a position that's arguably stronger than parallel Humean views about desire. ${ }^{16}$ The far-reaching implications of these Humean views have inspired a tremendous amount of philosophical attention. I offer this observation not as an argument against romanticism, but as a partial explanation of why such views are controversial and worth considering carefully.

Second, consider a parallel dialectical fact. It is well known that Humeans must confront putative counterexamples that pump intuitions about the irrationality of some underivative desires (see Parfit 2011; Quinn 1993). Romantics must confront potential counterexamples of similar types. Suppose that I know everything about Hitler's attitudes and his Final Solution. Suppose also that I am (secretly) a Jew; and that I love many other Jews who are being persecuted by the Nazis. I come to love Hitler, enter into an intimate relationship with him, love him more than my innocent family members, and continue loving him until the grisly end of our days. Is my love for Hitler beyond the pale of reason? Or is my love unjustified and inappropriate-something that reflects poorly on my character as a rational agent?

My view is that it is inappropriate, unjustifiable, and contrary to reason for me to love Hitler in this way. I find these claims no less plausible than the claim that it is regrettable for me to love Hitler in this way, and no less plausible than the claim that it is loathsome. Romantics tend to disagree: they often endorse these latter evaluations while rejecting the former as inapt. This frames a delicate set of issues. A weak version of moral rationalism, applied to mental states, claims that if you are morally required to have (or lack) some mental state, then you have at least some reason, all things considered, to have (or lack) it. ${ }^{17}$ Suppose this controversial view to be true. Then if there were legitimate moral evaluations of love, this would entail that there are reasons for love full stopassuming that the requirements of morality generated full-stop reasons of the right kind. Whether reasons of the right kind would in fact be generated raises difficult issues which have not been satisfyingly discussed by philosophers writing on reasons for love, and which I cannot explore adequately here. ${ }^{18} \mathrm{I}$ offer

16. Consider also Zangwill's claim (2013: 309, 311) that fear, anger, and pride are subject to rational constraints in the light of beliefs and other attitudes, whereas love is not.

17. For example, if you are morally required to be grateful for a gift, then you have at least some reason, full stop, to be grateful for it. This is a weak version of "mental state moral rationalism" because the moral requirement only entails the presence of a reason, rather than a sufficient or requiring reason.

18. Compare Hieronymi (2005) for the right vs. wrong kind of reason distinction, and D'Arms and Jacobson (2000) for a critique of the "moralistic fallacy" that may extend to the view sketched in this paragraph. Note, however, that the latter authors only claim that an emotion can be fitting 
these tentative remarks in an exploratory spirit. They play no role in my subsequent arguments about romanticism.

My reaction to such stock counterexamples is not idiosyncratic (cf. Jollimore 2017: 14). Nor is it universal. Smuts (2014a), for instance, bites the bullet with admirable forthrightness. ${ }^{19}$ The point here is modest: arguments by counterexample underline the controversial character of the Zangwill-Smuts version of romanticism, and the importance of investigating it. At the same time, we should recognize that such arguments do little to convince those with different philosophical sensibilities. My goal going forward will be to critique the roots of attraction to romantic ideas in ways that have more dialectical cachet. We can make progress on understanding romantic inclinations without relying on vexed intuition scoring.

To conclude the stage setting, I present one additional idea that is importantly connected to romanticism, and then briefly contrast romanticism with an alternative family of views about love's normative status.

David Velleman (1999) and Kieran Setiya (2014) claim that humanity itself is a sufficient reason for love: that you are a human being, any human being, justifies loving you. ${ }^{20}$ In one sense this view's proponents must deny the strong romantic theses just articulated, since they endorse rather than reject the existence of reasons for love, and endorse the aptness of some associated assessments (i.e., the assessment that love is justified). However, the view also insulates love from a set of evaluations that many of us find legitimate. It implies, for instance, that my love for Hitler in the above example is appropriate or justified. The idea that love (for human beings) is never unjustified seems to me a half strength version of romanticism. It is not as counterintuitive as full strength versions, but it still envisions love as an interesting outlier in moral psychology, with a relation to reasons that is unusual. After all, it is common to say that (e.g.) admiration, anger, gratitude, jealousy, and fear are sometimes unjustified. ${ }^{21}$

while also being morally wrong. For a number of reasons, that claim does not entail that one can be morally required to have an emotion while also having no reason to have it.

19. It is unclear to me whether Smuts can coherently say the following, however (2014a: 103): "it is not that love of Hitler is inappropriate, but that finding him attractive shows a monstrous indifference to horrific evil." For he must, and does, claim that Hitler is not objectively unlovable. But his being unlovable (or horrifically evil) is precisely what explains why loving attraction to his character is monstrous! Similarly, I wonder how Zangwill is entitled to claim (2013: 310) that "love can be assessable and more or less appropriate without being more or less rational." Judgments of appropriateness are paradigm cases of judgments about reasons. I may be misunderstanding the difficult passages in question. I ignore them in what follows.

20. As Velleman (1999) puts it, love is an optional but always permissible response to personhood. I ignore the difference between humanity and personhood here, though it is important.

21. My point here does not require that there be no other cases of morally significant mental states that are supported by reasons, yet never prohibited. Imagine forgiveness is always permissible (compare Pettigrove 2012). This might be due to some special feature of forgiveness that would 
"Rationalism" is a family of views about love that romantics reject by definition. Rationalists claim that there are reasons for and against loving, and hence that love is the kind of psychological state that's beholden to norms of justification. I am tempted to say that rationalist views are also committed to the following antiFrankfurtian thesis: some reasons of love are not love-relative (i.e., not generated by or grounded in love). This thesis is clearly endorsed by those who hold that love is justified by the objective value of the qualities of the loved object (the so-called Quality View, often attributed to Keller 2001, but see below). It is also endorsed by those who hold that love's reasons are grounded in both independently valuable qualities of the beloved and qualities of the relationship between lover and beloved (e.g., Jollimore 2011; 2017; Naar 2019; Wolf 2010); and by proposals that ground reasons for love in the lover's well-being (Brogaard 2015).

However, Niko Kolodny's (2003) relationship theory might give us pause. The theory is usually characterised as a rationalist one, including by Kolodny himself. But according to Kolodny, love is justified by the value of one's relationship with the beloved. ${ }^{22}$ And this can appear to imply that all reasons for love are grounded in love, or more precisely in loving relationships. There are interpretive questions here about Kolodny's view that I will not pursue, as these issues will not be crucial in what follows. ${ }^{23}$ We can now turn to my guiding question about what might support romantic views.

\section{The Appeal to Love's Blindness}

I call the first style of argument the appeal to love's blindness. Blindness arguments are commonly framed with literary examples, like the one from Raymond Gaita's memoir cited above. The examples suggest that love is akin to a form of sickness or madness (see Don Quixote), or an irrepressible urge (see

not apply to love, leaving love's universally permissive rational structure still in need of explanation. I'm inclined to reject this view about forgiveness. But arguing for a general thesis about the connection between rational governance and prohibitions would be a massive undertaking. I will make some observations about half strength romanticism throughout, but my main arguments will not depend on contentious thoughts about this popular idea.

22. Compare Abramson and Leite (2011: 674), who object to Kolodny's view precisely on the grounds that it makes the relationship into love's primary object, rather than the beloved.

23. One reason to think that he too will endorse the anti-Frankfurtian constraint is this: reasons against loving can presumably be grounded in facts that are not facts about loving relationships. For instance, if I have a spiteful and vindictive relationship with Darlene, then presumably I have reasons that support my not loving her (i.e., my not loving her may be justified). Reasons against loving are underexplored in the literature. Nonetheless, claims like this one are plausible and relevant. So I suspect it is safe to classify Kolodny as a rationalist while holding fixed the antiFrankfurtian criterion. 
Madame Bovary ${ }^{24}$ ) - a blind force of nature, in other words, that overwhelms our agency.

Here is one provocative statement of a blindness argument:

We can work at trying to love someone, but it seems to just happen or not. No matter how good we think that someone is, we may or may not love them. Love, at least to some degree, just does seem to be a matter of chemistry. And chemistry is not responsive to reasons (Smuts 2014a: 96). ${ }^{25}$

I will consider two more rigorous formulations. I cannot be certain that romantics would accept my paraphrases. But they are fair-minded attempts that I believe to be helpful. Here is the first attempt.

1. Love just happens. ${ }^{26}$

2. Things that just happen are not under our control.

3. So love is not under our control.

4. Things that are not under our control are not governed by reasons.

5. So love is not governed by reasons.

This version expresses a familiar and intuitive connection between somewhat nebulous intuitions about "just happening" and more developed judgments about control and reasons. It captures part of what we saw Gaita observing about his father's love mania. For the young Raymond "it was never a question of justification" precisely because "sexual love was a passion whose force and nature was mysterious" (uncontrollable, akin to madness).

However, the argument is not compelling. Its flaws are illustrative.

The first problem is with premise 1 . The proponent of the argument is clearly thinking of "falling in love." Moreover, he is in thrall of we might call the Cupid Model, in a sense that should be self-explanatory. ${ }^{27}$ Now the Cupid Model may

24. Flaubert (1904: 125): “Love, she thought, must come suddenly, with great outbursts and lightnings - a hurricane of the skies, which falls upon life, revolutionizes it, roots up the will like a leaf, and sweeps the whole heart into the abyss."

25. See also Frankfurt (2004: 38), Zangwill (2013: 305-307).

26. In the cited passage, Smuts takes the idea that we cannot make ourselves love someone as evidence that love just happens. I take the latter to be the crucial claim. Yet it is worth noting that the former claim is vague, and in some senses false. Working on loving someone is possible, and at times succeeds. This is especially familiar in valuable relationships (e.g., between spouses or family members) where the love has faded. Compare Murdoch's (1970) famous example of M's newfound loving attention.

27. Compare Zangwill (2013: 312): "on the arational picture of love, the particular differentiating features of the beloved that we are aware of are causes of love not reasons for love. They are like cupid's arrows." 
be right about the initiation of a certain kind of psychological process. Some forms of intense attraction, for instance, are indeed the kinds of things that just happen. And there is a basis for thinking that these forms of attraction are often deeply insulated from justification. There is no justifying an attraction to certain smells rather than others. Yet there is much more to romantic love than this kind of embryonic attraction.

An extremely common view, held by most philosophers of love since Plato, is that romantic love necessarily involves a particularly intense desire for the good of the beloved. ${ }^{28}$ Though such a desire could in principle arise as spontaneously as a spell of dizziness, this is not the usual genealogy. When we narrate actual stories of romance we tend to describe processes constituted, in part, by many deliberately undertaken intentional actions, actions that contribute to escalating passion and commitment over time. ${ }^{29}$ Though there is no clearly identifiable point at which initial attraction and affection become genuine romantic love, there is widespread agreement that the love outcome is anything but a foregone conclusion. For this reason, we should deny that romantic love is identical to the psychological phenomena we are tempted to describe with Cupid metaphors. We should say instead that romantic love is one possible outcome of a process whose initiation is, sometimes, aptly described in this way. We should therefore reject the premise even in the motivating case of romantic love.

Some may balk at this argument because they accept the possibility of "love at first sight." The challenging issues raised by this notion warrant a few brief remarks. First, my opposition to premise 1 , as applied to romantic love, could survive the possibility of love at first sight. Even if romantic love sometimes just happens, it usually does not. At best, this would leave the argument's proponent with fuel for her fire in some special cases. Second, we should be agnostic about the possibility of romantic love at first sight. I am not familiar with any convincing arguments for this possibility, and intuitions about it should be taken with a grain of salt..$^{30}$ Alternative explanations are ready to hand: what we call love at first sight may be a romantic re-description of the memorable first encounter

28. We might add that the desire is stable and non-instrumental. It would be tedious to list all those who accept this view, but compare the taxonomy in Helm (2017). Dissenters include Velleman (1999) and Badhwar (2003).

29. Compare Naar (2013) on love's non-static character, and Veaux and Rickert (2014: 260) on how we should avoid mistaking NRE ("new relationship energy") for love itself.

30. Smith (2017: 153) asserts that love at first sight "doesn't seem to be impossible." Hurka (2017: 178, note 2) asserts in response that strong attraction to qualities is possible at first sight, but that genuine love for an individual is not. Compare Abramson and Leite's (2018: 5) comment that "it is inappropriate for an adult to form, not just a crush, but a full-fledged romantic love attachment on a complete stranger." Maurer (2014) gives the only essay-length discussion of the phenomenon that I've seen. His conclusion is that "love at first sight" should not be treated as a kind of love. 
between future lovers, whose eventual terminology reflects the confidence of hindsight; or it may be an apt expression of the confidence of lovers who know from the first encounter that they will fall in love. Third, it is odd, and revealing, that this phenomenon is so closely associated with romantic love. In evaluating the plausibility of premise 1 we should widen our lens.

Do loving friendships just happen? It is difficult to understand the suggestion. To be sure, relationships that come to be intimate friendships are often initiated by an attraction to personal qualities. This attraction can just happen, much like sexual attraction. However, as moral philosophers have frequently observed, friendship itself can be among our most important expressions of rational agency and self-definition. ${ }^{31}$ As feminist philosophers in particular have emphasised, friendship can be liberating precisely because it is a domain of love in which we exercise judgment and choice (Friedman 1989; hooks 2000: 133). Adult friendships, at least, generally develop as a result of reflective engagement with personal characteristics, and they are constituted by patterns of deliberation and shared planning - which is of course not to deny that they are also constituted by largely non-volitional affective states. None of this could be much surprise to those familiar with Aristotle's still unmatched reflections on friendship (Aristotle 1997; Nehamas 2016: Ch. 1). More controversial, perhaps, is the view that genuine romantic love usually involves loving friendship. ${ }^{32}$ Since I endorse this view, I think these observations about friendship help to cement the conclusion that premise 1 is false not just when applied to love in general, but also when applied to romantic love specifically.

Parental love may be the best source of motivation for the claim that love just happens, notwithstanding its conspicuous absence from most discussions of blindness arguments. We describe new parents as "spontaneously" overcome when their children arrive. Yet these parents have actually engaged in substantial projects of love-cultivation. Procreative parents devote themselves intensely to gestating children, and develop affectionate attachments along the way. A similar point applies to most adoptive parents, who navigate onerous processes prior to actually uniting with their children. This is not a decisive argument against the possibility of "parental love at first sight," however, because there are intriguing non-standard examples. Might a father come to love his newborn daughter immediately upon meeting her, precisely because he is told only then of his parenthood and her existence?33 I can remain agnostic about how to anal-

31. See especially the Drawing View of Cocking and Kennett (1998).

32. I say "usually" so as not to foreclose the possibility of unrequited love. Compare Protasi (2014).

33. For some stimulating cases in this vicinity compare Ferracioli (2017). Similar questions can be asked about the love of young children for their parents. 
yse these difficult examples, just as I can remain agnostic about the possibility of romantic love at first sight. Romantics aim to defend a general thesis about love, not an interpretation of a few unusual cases.

These observations are an illustration of my methodological point about the romanticising of our love discourse. Paying more attention to non-romantic love complicates our judgments in illuminating ways.

The above version of the blindness argument has another flaw: premise 4 is false. Virtually all epistemologists agree that belief is rationally governed. There are reasons for belief and norms on believing, whatever their precise character turns out to be. Yet we don't have much control over our beliefs. The applicability of epistemic norms, in any given case of believing, does not depend upon the ability of the believer in that case to decide what to believe. ${ }^{34}$ But the analogous thought - that we cannot love at will-is what Smuts appears to think supports his conclusion that love is not governed by reasons. 35 The conclusion cannot follow, on pain of falsifying our assumption that belief is governed by reasons. ${ }^{36}$

We now consider a second way to understand blindness arguments. This interpretation dispenses with the claim that love just happens, and in doing so sidesteps issues about the connection between control and rationality. The key idea driving this version of the blindness argument is that love does not reliably respond to reasons.

1. Love is frequently insensitive to reasons (or to what the reasons would have to be, were they to exist).

2. If a state is frequently insensitive to reasons (or to what the reasons would have to be, were they to exist), then it is not governed by reasons.

3. So love is not governed by reasons.

Again, the argument expresses common ideas, like the idea that love is not in fact proportioned to the intrinsic goodness of the beloved. ${ }^{37}$ Again, we should not be persuaded, because the crucial premise 2 is false.

34. Compare Steup (2001: Ch. 4), who argues that we can successfully decide to believe, but that this is a rare phenomenon.

35. This is suggested by the claim that "we can work at" love, but ultimately it just happens or not. The claim about love not tracking our goodness judgments is distinct. It is the focus of my second version of the blindness argument.

36. For simplicity's sake, I have not distinguished between direct and indirect control. Do we have more indirect control over our beliefs than we do over our loves? I have no clue how one would try to answer this question.

37. See de Sousa (2015: 75): "I conclude that love does not derive from reason, virtue, or Kantian core rationality. It is largely the offspring of chance: in proximity, order of acquaintance, pheromone compatibility, genetic influences, and accidents of taste, transference, and habit." For other authors who appear sympathetic to something like this blindness argument, see Frankfurt (2004), Goldie (2010), Grau (2010), Smuts (2014b), and Zangwill (2013). 
Love for a person need not issue from a reflectively composed catalogue of reasons for loving them. Further, love often arises or persists in the face of what appear to be relevant, even decisive reasons against loving. But these observations cannot show that love is not governed by reasons. We should make an important though often muddled distinction between reasons sensitivity and rational governance.

Take a token mental state, like my belief that I am an exceptionally good driver. That mental state may be deeply insensitive to reasons: I might maintain the belief even after several accidents provide me with ample evidence that it is false. ${ }^{8}$ Still, I am rationally required to revise the belief, notwithstanding the fact that I am not disposed to do so. The norms governing this mental state are not underwritten by its sensitivity to them.

The point generalises. Consider a type of mental state, like belief. When psychologists document our pervasive tendencies to believe irrationally-by showing our susceptibility to various biases, for instance-they do not thereby undermine the claim that the beliefs in question are governed by reasons. On the contrary, one of their laudable goals is to help us notice our irrational proclivities, so that we can devise strategies for better resisting them (see Kahneman 2011).

Many other mental states are governed by at least some rational norms while being, in individual cases and as a general rule, substantially insensitive to reasons. Plausible candidates include intention, fear, anger, antipathy, shame, empathy, resentment, jealousy, envy, gratitude, admiration, and appreciation. Premise 2 would prove too much. One can accept the interesting starting point of this blindness argument - the claim that love is often insensitive to reasonswhile rejecting its romantic conclusion.

Should we accept this starting point, however? It is a dogma of romanticism, inescapable in folk moral psychology, that romantic love is especially insensitive to reasons. One canonical interpretation: love is super-frequently or super-deeply blind to the good-and-bad-making features that would appear, prima facie, to count as reasons. ${ }^{39}$ And there are interesting questions, related to ought-implies-can theses, about what super-frequent or super-deep insensitivity would imply about governance. Whether the frequency and depth claims are true, however, depends on the character of love's (putative) reasons, and on the relevant comparison class.

38. I here assume that evidence constitutes, or grounds, epistemic reasons.

39. I think this is the most common meaning of the expression "love is blind." Compare the obsessive love described in Sabato (2011: 127): "The more I thought about it, the more receptive I became to the idea of accepting her love without condition, and the more terrified I became of being left with nothing, absolutely nothing. From that terror was germinating and flowering the kind of humility possessed only by persons who have no choice." 
I will make several claims about the character of love's reasons in what follows. Presently I offer a simple observation about reasons in the context of romance. Many people seek and offer advice about romantic relationships. Presumably some such advice is good advice. What makes it good? An attractive view is that good advice is advice that's sensitive to the relevant reasons. Sometimes these will be reasons to commit or re-commit to a relationship, or reasons to end one. Reasons to begin, continue, or end a relationship are not the same as reasons to begin, continue, or end loving. But they are related.

Suppose you begin dating someone whose personal qualities you admire, whose company you enjoy, who understands what you are all about, and who treats you better than any previous partner has. Here is some advice: continue dating this person. Here is one reason the advice is good: you may well come to love this person and have a flourishing relationship with them (cf. Abramson \& Leite 2018: 11). Happily, there are many romantic lovers for whom this advice was at one point good, and for whom the prediction came true. Far from being especially insensitive to reasons, their love seems like it may be the only apt response in the circumstances. $4^{\circ}$ Similar things can be said about the sadder side of the coin. Reasons for ending relationships are often intimately related to reasons for withdrawing love.

Any argument for the claim that love is super-frequently or super-deeply insensitive also depends on the selection of a relevant comparison class: love must be especially insensitive to reasons when compared with some broader set of phenomena. So what is the relevant class? I know of no careful discussion of this issue.

A natural suggestion is the class of emotions. ${ }^{41}$ Consider anger. I agree with Amia Srinivasan (2017), who claims (contra Nussbaum 2016) that anger is often apt. This does not tell against the ubiquity of irrational anger, which is the focus of, among other things, a great deal of current political analysis. Consider fear. There are many warranted fears, and then there are the massive complexes of irrational fears that sustain psychiatric practices and fascist regimes. Consider jealousy. I'm not sure what would ground appropriate jealousy, but I'm confident that jealous people frequently know they lack any such grounds. (In my own case, this is one of the most painful features of the condition!) This last

40. I'm inclined to think that some happy cases do license this strong conclusion-something like a "requirement" to love, or at least to facilitate the blooming of it. My main claims in the text do not require this commitment. I could instead say, as others do, that the love is warranted or fitting, without being required. See Section 3.

41. Above I noted that Zangwill (2013: 309, 311) contrasts fear, anger, and pride, which he thinks are subject to rational constraints in the light of beliefs and other attitudes, with love, which he thinks is not. This is an assertion about an asymmetry in governance. It is not an argument for an asymmetry in degree or frequency of sensitivity. Zangwill does appear to assume that the relevant comparison class is the set of emotions. 
example licenses a speculative remark. Perhaps romantic intuitions about love's insensitivity are, in part, disguised thoughts about the green-eyed monster, which seems both especially insensitive to evidence and especially noxious for good reasoning and conduct. Some connections between these themes and presumptions of sexual exclusivity will be explored in a preliminary way below. For now, we must say that prospects for the thesis that love is uniquely insensitive look dim.

The last few paragraphs have considered a thesis about romantic love. Even if the reader rejects my claim about that phenomenon, she may still agree that parental love tends to be highly (though of course imperfectly) sensitive. If we started our thinking with this innocuous observation, instead of hazy claims about romantic love's special insensitivity, then we would be confronting the shadow of a romanticized discourse. This confrontation is constructive.

I close this discussion with two observations. The first concerns the againstthe-grain thesis that love is a state of heightened sensitivity to reasons. The second is a suggestion about alternative conceptualisations of blindness arguments, which I offer as an olive branch to intrepid romantics.

For Iris Murdoch (1970), love involves an unusually keen vision of another. It is unusual because our normal non-loving vision is distorted by the inevitable impositions of the "fat relentless ego." Whereas romantic love, intimate friendship, and familial love can be privileged vantages, relatively free of egodistortion, from which we see a person for who she most deeply is. It is in such intimate relationships that the contours of our personal dramas, and the subtleties of our characters, are truly revealed. So only our intimates have the materials to appreciate all in us that is worth appreciating. ${ }^{42}$ Love from our intimates need not be primarily a response to our personal qualities, and it need not be justified by these personal qualities (see Section 3). But it may be and often is. This special kind of sensitivity is, I submit, a better explanation of love's value than the insensitivity often gestured at by romantics. 43

Now for a positive suggestion about how blindness arguments might be resuscitated. The idea to be vindicated is that love is insensitive to reasons in a special way. Consider Thomas Hurka's (2017: 171) claim that the start of love is

42. Compare, to take just one obvious example, the love of places. Having lived in Sydney, I am in a position to appreciate its wonderful qualities. These qualities make my love appropriate. Someone who has merely visited Sydney cannot appreciate these qualities as deeply. And it would be universally acknowledged that someone unacquainted with Sydney could not love it.

43. None of this implies that love cannot also be the source of profound degradations of reason. Compare Nussbaum's (2004) brilliant discussion of love's deliriously "secret knowledge" in Murdoch's The Black Prince. A subtle contrast is worth noting. The degradation of reason is probably only a contingent consequence of love (albeit a common one). Whereas I read Murdoch as saying that love is to be identified with vivid perception of the beloved's nature, and accompanying appreciation of her goodness. 
"partly a realm where your desires can permissibly fix on neutral traits." Rationalists like Hurka tend to acknowledge that there is considerable latitude in warranted loving - at least in the initiation of friendship and romance. Suppose I come to love Mariano and not James, even though both have a variety of nice personal qualities. The explanation may be just that I like the cut of Mariano's jib. The romantic will doubt that rationalists can explain the permissibility of such selectivity. Love is insensitive to reasons in a special way, they will claim, because love for one person rather than another cannot be justified. 44

I'm skeptical. Affinities should not be excluded from the domain of love's reasons. Hurka articulates a general feature of permissible desire, not a specific feature of desire in the context of love. I am warranted in wanting the beer I like better; this desire is not merely explicable, but positively sensible. Here though is a conciliatory proposal. Liking the cut of Mariano's jib is a reason for me to spend more time with him. (I'm cantankerous about jib cuts). And it is widely recognized that the selectivity of love must be in part explained by the selectivity of the history of our personal relationships. 45 Once I have (reasonably) spent more time with Mariano, I may (reasonably) come to love him. At this point, it is appropriate for me to love him rather than James. In short, my affinity helps to justify the developing relationship, and the relationship helps to justify the developing love.

I have argued that extant blindness arguments are unsuccessful. However, the next argumentative strategy might be thought of as a kindred attempt, which articulates one special way in which love is peculiarly related to reasons.

\section{Old and New Loves}

I will now critique the two most influential arguments for romanticism in contemporary philosophy. It is essential to clarify the dialectical role that these arguments are standardly taken to play: they are negative arguments against rationalist views of love that are sometimes claimed to leave romantic views as the best remaining option. ${ }^{6}$ Since there are many ways for rationalists to respond to these arguments, I doubt that they can provide any support for romantic views at all. Nonetheless, investigating them is a crucial source of insights about how romanticism has been conceived, and about the nature of love more generally.

The "trading up" argument has been at the core of philosophical discussions

44. See Naar (2019), a rationalist who is very concerned about this challenge.

45. Compare accounts as diverse as those of Velleman (1999), Kolodny (2003), and Abramson and Leite (2011).

46. Kolodny (2003) mentions this dialectical move but does not endorse it. Zangwill (2013) and Smuts (2014a) endorse it. For a critical discussion see Jollimore (2011: Ch. 6). 
of love since its influential presentation by Robert Nozick (1989). It has been thought problematic for rationalism, because it has been thought problematic for the Quality View, which critics regard as the default version of rationalism. Here is one illustrative statement:

Story: $\quad$ Billy loves Jamie.

Suppose: Love is justified by the qualities of the beloved, as the rationalist claims.

Imagine: Jimmy comes along, and he has even better qualities than Jamie.

Therefore: Billy should start loving Jimmy instead!

Objection: Someone willing to trade up in this way is not a genuine lover.

Conclusion: We must reject the assumption that love is justified by the qualities of the beloved. So we must reject rationalism.

A related generalisation of the idea: the Quality View says that love is justified by the positive qualities of the beloved. But for any positive quality we choose, there will be many people who possess it. Yet we only love some of those people, and this seems ok. So the quality view must be incorrect, and rationalism must be rejected. 47

The second influential argument concerns the irreplaceability of the beloved. It is worth distinguishing this argument from a misguided predecessor, which has also sustained philosophical interest in romantic views. According to the older argument, rationalism, or at least the quality view, implies absurdly that we love properties rather than persons (Vlastos 1999). This is implausible. One's reasons for believing something need not be identical to the object of that belief. The same distinction between reasons and objects applies to various mental states. Just as I can appreciate a painting because of its features, I can love a person because of her characteristics..$^{8}$

The more currently in vogue irreplaceability worry goes like this: 49

47. Jollimore (2011) calls this the promiscuity problem, and distinguishes it from worries about trading. Compare Smuts (2014b: 520-521).

48. Compare Delaney (1996: 343), Keller (2001: 165), Kolodny (2003: 154), Grau (2010: 260), Helm (2010: 24), Abramson and Leite (2018: 14). A different version of the argument claims that we value being loved for our personhood rather than our properties (see Velleman 1999; Zangwill 2013: 308), and thus that only this kind of love can be worth having. It is curious for romantics to endorse this argument, which appears to move from an evaluation of love to a condition on its nature. But there is a more direct objection, which is that the claim about what we value is false. Many of us value being loved by romantic partners, friends, parents, and siblings at least partly for our personal traits.

49. See Kraut (1987), Kolodny (2003), Grau (2010), and Smuts (2014b). 
Story: Billy loves Jamie, but Jamie dies. Some time later, a super scientist presents Billy with a perfect duplicate of Jamie ("Jamie 2.0").

Suppose: Love is justified by the qualities of the beloved, as the rationalist claims.

Therefore: Billy should love Jamie 2.o.

Objection: Someone willing to replace in this way is not a genuine lover.

Conclusion: We must reject the assumption that love is justified by the qualities of the beloved. So we must reject rationalism.

In other words: love does not accept qualitatively identical substitutes; it is governed by a requirement of non-substitutability. But if love were justified by qualities, it would accept such substitutes. So love cannot be justified by qualities (Smuts 2014b 520).

The trading up and irreplaceability arguments are closely related. Many have thought them to be compelling refutations of the Quality View..$^{50}$ There is less agreement about whether they motivate romanticism, the relationship view of Kolodny (2003), or some other version of rationalism. I now offer three sets of observations about these arguments, which collectively undermine their force as motivations for romanticism, and suggest various positive theses about how rationalists should conceive of reasons for love.

\section{First Observation: The Exclusivity Assumption}

The trading up argument enshrines a controversial assumption about the nature of romantic love. It would not be a general truth about love even if it were true in that special case, which it is not.

While it purports to provide an argument against the Quality Viewtraditionally considered a position about personal love in general-the trading up worry is nonetheless ubiquitously applied to romantic love in particular..$^{51}$ One reason to reject it is that it assumes that romantic love must have only one object at a time.

50. For a recent discussion see Setiya (2014). Goldie (2010: 64) is representative: "Fear should be felt in proportion to the fearsomeness of the object's determinate properties, whereas love of someone should not be felt in proportion to the loveableness of the object's determinate properties." This is correct but, as we will see, no objection to rationalism per se.

51. See Smuts (2014b: 520), an excellent article that is otherwise careful about treating multiple forms of love. 
The argument's proponent asserts that if Billy loves Jamie (romantically), then his coming to love Jimmy (romantically) would amount to "exchanging" (Smuts 2014b: 520; Zangwill 2013: 303). This presupposes that polyamory is impossible. Philosophers consistently demonstrate that they are relying on this assumption by asserting without comment that subjects in the cases at issue could not be genuine lovers - and by analogising them to characters that treat people like they were fungible automobiles (Goldie 2010: 64)..$^{52}$

Many people identify as polyamorous. Strong reasons must be provided for dismissing their testimony. Nor is it wise to ignore challenging recent work that critiques the longstanding mythology of sexual exclusivity (Brunning 2018; Jenkins 2017; McKeever 2017).53 It seems to me obvious that polyamory is possible, but more germane is the fact that its impossibility cannot be assumed.

One conclusion: the notion of trading is a red herring, because the interesting question is not about exchange. It is about coming to love someone when you already love someone else.

Another conclusion: even if the argument were plausible regarding romantic love, it would not be generally plausible, because the analogue of the exclusivity assumption is a non-starter in other contexts. Philosophers have systematically underappreciated this point, and in doing so simplified the complex topic of new love and its reasons.

Compare intimate friendship. Nobody claims that gaining a new friend means trading in an old one. Why is there no expectation of friendship-exclusivity? Is it only sexual jealousy that explains the asymmetry? Insightful responses to this puzzle must excavate our assumptions about romantic exclusivity rather than appealing to them unquestioningly. .54

Similarly, nobody claims that a mother's love for her second child involves betrayal of her firstborn. Still, new parental love is interesting. Coming to love

52. See Jenkins (2015) for further examples of the "modal monogamy" assumption. Nozick (1989) is an interesting case. Part of his aim is to articulate the sense in which romantic love is different from friendship, and he does so by assuming that monogamy must be part of the distinctively romantic "we," which involves (unlike friendship) the sharing of an identity. As Jenkins notes (2015: 178), his claim is that polyamory is not "feasible," rather than that is impossible (1989: 84). His argument is unpersuasive, and the feasibility claim has been undermined by contemporary social practices. But at least Nozick tries to argue for his view. More recent discussions of the trading up argument seldom give polyamory any serious consideration.

53. It is especially curious that our tradition has so often ignored this possibility given that we owe some of the most important discussions of love in Western philosophy to the ancient Greeks, whose non-monogamous practices of erotic love are widely discussed.

54. See McKeever (2017: 359). I have not claimed that friendship and romantic love are identi$\mathrm{cal}$ in character or governing norms. For one thing, romantic love is often practiced in the context of explicit promises of monogamy, such that coming to love a new person romantically amounts to violating a morally important commitment. 
other children more than one's own seems terrible (Kolodny 2003). And the Quality View seems particularly odd as a theory of the justification of parental love (Setiya 2014). These notes set up my next set of observations.

\section{Second Observation: The (Non-Relational, Requiring) Quality View}

Both the trading up and irreplaceability arguments target a version of rationalism that we never should have expected to be true: the Non-Relational, Requiring version of the Quality View (often called, misleadingly, the Quality View). There are more defensible versions of rationalism that are not undermined by these arguments. So the arguments cannot motivate the denial of rationalism or the acceptance of romanticism.

The arguments assume, first, that for rationalists, love must be justified by the qualities of the beloved, where those qualities are non-relational properties such as wit or beauty. ${ }^{55} \mathrm{I}$ 'm not sure any philosopher has defended this view. ${ }^{56}$ And for good reason: there is no pressure to endorse this arbitrary constraint on the sources of justification. Most obviously, Billy's love for Jamie will be partially justified by the value of their longstanding relationship with one another. Jimmy's nice qualities cannot ground that sort of reason, which in many circumstances is especially weighty. Nor can the properties of Jamie 2.0.57

This point is by now familiar, so the persistent allure of trading and replacement arguments is puzzling. Here is an argument to bolster the conclusion, which shows that we should never have expected the Non-Relational Quality View to be correct.

Consider a general question: what justifies our projects or commitments?

55. Compare Grau (2010: 261): “love's bond does not seem to consistently and proportionally track alterations in qualities in the manner one would expect if all it is to love someone is to love their qualities. It is not uncommon for love to survive significant alterations and to even survive alterations for the worse." I set aside substantial issues about whether allegedly non-relational properties are really non-relational.

56. For instance, Keller (2001: 166) explicitly rejects the Non-Relational Quality View. Compare also Abramson and Leite (2018), who sometimes appear to claim that reasons for love must be grounded in the beloved's good character, but who also appear to admit reasons grounded in valuable relations with the beloved.

57. See Hurka $(1997 ; 2017)$ for the claim that historical properties can justify love. Kolodny's (2003) relationship theory is designed to avoid these worries. There are debates about whether it does so entirely (Smuts 201a: 520; Zangwill 2013: 310). After all, you might rationally believe that a better future relationship is in the offing. There are other important objections to the relationship theory, besides the already mentioned criticism about how it conceives of love's object (see Protasi 2014 on unrequited love, and Smuts 2014a: 521). But rationalists can endorse the general insight from Hurka and Kolodny without endorsing the more contentious features of Kolodny's theory. 
Suppose that tomorrow I come to believe that physics is more intrinsically valuable than philosophy. Would it follow that I should drop philosophy and take up physics? Clearly not: I have a long history with philosophy that rationalises my continued devotion to it. I have students who depend on me, former teachers who would be disappointed to see me leave the field, colleagues who I would miss engaging with philosophically, unrealised ambitions that it would be a shame to abandon, etc.

In sum, crucial to the justification of projects are relations between subject and object-historical relations between persons and projects that are in some ways analogous to historical relations between persons. Since love is a particularly intense type of concern and commitment, we might expect this truism about rational justification to carry over. Far from being an ad hoc response to a romantic objection, then, the rationalist rejoinder is a plausible generalisation from widely accepted theses about the structure of practical reason.

Besides assuming that rationalists accept the implausible and unpopular Non-Relational Quality View, the trading and replacement arguments assume that rationalists accept an especially strong implication of it: that positive personal qualities generate requirements to love..$^{5}$ The rationalist can deny that reasons for love must always have this strength (Abramson \& Leite 2018; Jollimore 2011). Reasons often support without requiring. This phenomenon is widely observed in discussions of mental states as various as intention, anger, and forgiveness (compare Little 2013 for an especially ambitious take).

Whether there are any requirements to love is controversial. The reader may have gathered that I am sympathetic to such requirements for many parents (Liao 2006); that I accept requirements to refrain from loving, for instance in the Hitler case; and that I am interested in the possibility of requirements to open oneself to romantic love and friendship love. ${ }^{59}$ None of these ideas resembles a blanket requirement to love on the basis of non-relational properties.

Common presentations of the trading and replacement arguments saddle rationalists with the doubly unattractive Non-Relational, Requiring Quality View. More charitable presentations would derive less provocative conclusions. Reasons for romantic love are usually grounded in a mix of relational and nonrelational qualities. This secures the familiar idea that quality-based reasons for loving a new person might be outweighed by reasons against loving them, for example, reasons grounded in a prior monogamous commitment to someone

58. Jollimore (2011: 17) is representative, though he is not impressed by the argument: "reason will require Alighieri to abandon Beatrice in favor of Carmen (on the assumption, at any rate, that he cannot love them both)." The "should" in my reconstructions (e.g., "Billy should love Jamie 2.0") has the same deontic character.

59. Incidentally, I also find plausible some comparative requirements-such as the requirement to love your dog less than your child - which are almost never discussed. 
else. And requirements to love romantically will be rare, if they exist at all. This secures the familiar idea that a friend cannot legitimately demand that I love her romantically, even when I appreciate many of her wonderful qualities. ${ }^{60}$

Curiously, we've seen that a reasonably popular half strength romantic view actually entails one of these conclusions. If it is always permissible to love any given human being, then it is always permissible to love in the circumstances so often ridiculed by proponents of trading and replacement arguments. But then half strength romantics are not in any position to offer these arguments - and those offering these arguments must reject half strength romanticism. This tension is interesting and underexplored.

I've outlined a version of rationalism that is independently plausible and immune to the trading and irreplaceability arguments. But perhaps the arguments still locate an important deficiency in rationalistic accounts. My third observation responds to this legitimate suspicion.

\section{Third Observation: Constancy}

The trading up and irreplaceability arguments conceal interesting nuances in common views about old and new love. When we appreciate and develop the kernel of insight embedded in these arguments, we see that it does not provide independent motivation for romantic pictures, and may offer additional evidence for rationalism.

Here is a suggestion about the basic idea that these arguments express: it is the idea that genuine love must be constant (see Rorty 1986: 399). But what assumptions about love's constancy do the arguments exemplify?

Reflections on these arguments sometimes conflate constancy and nonfungibility. Everyone should accept a non-fungibility thesis: when I come to love someone new, I do not thereby replace one of the irreplaceably valued people I already love. ${ }^{61}$ Treatments of these arguments also at times suggest that love's constancy is implausibly stringent. Everyone should agree that loving relationships end very often, and that many should end - not just the relationships, but also the love. ${ }^{62}$ Our ideal of constancy must be compatible with these prosaic insights.

6o. Darwall (2017: 100). Compare Srinivasan's (2018) claim that though sexual desire should be critiqued, it cannot be demanded. See Rose (2018) for a stimulating exploration of the ways that maternal love is frequently demanded by individuals and by society at large.

61. This is an explicit theme in all sensitive discussions of polyamory. Compare Veaux and Rickert (2014: 140).

62. Sometimes the end is precipitated by a new love, which throws into relief the inadequacies or toxicities of an old one. Willingness to change one's love life-to change the objects or strengths of one's love, in romance, friendship, and even sometimes the family-can display virtues like flexibility, self-determination, resilience, and optimism in the face of heartbreak. Resis- 
Properly understood, loving constancy is a great virtue, accounting for some of the most beautiful features of long-term romantic love, friendship, and familial relationships. I will now offer some remarks about how to best understand it.

Consider the distinction between metaphysical and normative conceptualisations of constancy. The trading up argument suggests that constancy is a metaphysical criterion: love that alters in certain ways is not love at all. There is some truth in this vicinity. Love is constituted by stable dispositions, such as dispositions to care for and be with the beloved, and inconstancy of some kinds is proof that the subject lacks the relevant dispositions. ${ }^{63}$ But love cannot require anything approaching maximal exclusive constancy. Genuine romantic love can end; new love can be better than old love; and new love can coexist with the old. Similar truths apply to intimate friendship. They apply to familial love as well, notwithstanding comforting (?) fictions about the unconditional love of parents.

These observations indicate that the content of a plausible metaphysical criterion of constancy will be minimal and vague. And that in turn suggests that our deeper concerns about constancy may really be normative. Instead of “Did he ever love me at all?" one wonders "How could he throw away our thirty years for that?"

A related worry about the irreplaceability argument supports this hypothesis. The argument trades on a noisy thought experiment that is not especially probative. Duplication of a deceased loved one is creepy, and we should not be unduly impressed by intuitions about it. Consider the following parody:

Story: Billy loves Jamie, but Jamie dies. Later a friend introduces Billy to Alex, who has virtues similar to Jamie's.

Suppose: Love is justified by the qualities of the beloved, as the rationalist claims.

Therefore: If Billy comes to love Alex, this love will be supported by reasons. ${ }^{64}$

Objection: Someone willing to replace in this way is not a genuine lover.

Conclusion: We must reject the assumption that love is justified by the qualities of the beloved. So we must reject rationalism.

tance to altering one's love life can be a personal catastrophe, exemplifying degraded agency, fear of change, and lack of hope. A natural hypothesis is that whether alterations in the objects and intensity of your love are rational will depend on the circumstances - for example, the character of the old relationship and the potential qualities of the new one (compare Brogaard 2018).

63. See Shpall (2018) for a more detailed account of love's nature that develops these ideas. Compare Hurka (2017) and Abramson and Leite (2018).

64. I've amended the preliminary conclusion in the way suggested by my comments about requiring vs. supporting reasons. 
Most readers will be flummoxed by this argument. There needn't be anything disturbing about Billy's coming to love Alex. "Replacement" is a crude way to characterize new love like this. ${ }^{65}$ Still, the terminology reveals our preoccupations. In some circumstances, new love does feel like replacement-when the lover appears unmoved by the value of her old relationship, for example, and happily takes up with a new partner while others are still devastated by the death of her previous one. The "later" in my story registers the normative expectation via its ambiguity.

All of this recommends understanding the virtue of constancy as a matter of appropriately responding to reasons. The virtuously constant lover is attuned to her weighty reasons for valuing historical relationships and the persons involved in them-and likewise attuned to how these reasons interact with reasons for valuing other persons, new experiences, and new modes of selfhood. The idea that love should never alter caricatures the forms of sensitivity to reasons that the appropriately constant actually exhibit. Here are some quick illustrations:

(1) There are excesses of constancy as well as deficiencies. Consider the abused wife who tragically holds firm "til death do us part." 66

(2) The requirements of appropriate constancy depend on the forms of particular relationships. Consider parental and filial constancy, which require huge changes in the character of love's expression over time.

(3) The virtue of constancy is sensitive to relevant differences between the beloved's qualities. Consider the plausible view that faithful lovers and friends especially value relatively durable qualities such as humour, kindness, and intelligence-and the associated idea that changes in superficial characteristics do not justify changes in love, but that changes in deep character may (cf. Abramson \& Leite 2018: 7).

(4) The lazy conflation of romantic constancy with sexual exclusivity trivialises the values of fidelity, and the ways that alterations in love can be wonderful. Compare the stable polyamorous lovers who cultivate the difficult emotion of "compersion" as a way of seeing and valuing one another as autonomous beings. ${ }^{67}$

65. Compare a remarkable passage from Austen's Sense and Sensibility (2001: 40):

"Your sister, I understand, does not approve of second attachments."

"No," replied Elinor; "her opinions are all romantic."

"Or rather, as I believe, she considers them impossible to exist."

"I believe she does. But how she contrives it without reflecting on the character of her own father, who had himself two wives, I know not."

66. It should go without saying that this may be lamentable and irrational without being blameworthy.

67. Compersion is a fascinating and poorly understood emotion: on one common conception, joy taken in a partner's romantic love for another. See Brunning's (2018) outstanding discussion of polyamory's special emotional work. 
These are only preliminary gestures at a fuller characterisation of the virtue of constancy. Nonetheless, they tell in favour of rationalist views, which affirm the existence of reasons for and against love, and which underline the importance of better conceptualising them.

\section{A Dialectical Note}

Suppose you are not convinced that, in the final analysis, the considerations motivating the trading up and irreplaceability arguments actually confirm rather than undermine the plausibility of rationalism. That is no support for romanticism.

To gain positive support from these negative arguments, romantics need to show at least two things. First, they need to show that rationalists who want to ground reasons for love in valuable non-relational qualities cannot also ground them in valuable relational properties. Second, they need to show that rationalists are committed to claiming that positive non-relational qualities often require love, rather than simply supporting it. Both claims are implausible. As I have argued, commitment is rationalised by both non-relational and relational facts. So too is love. Likewise, requirements are far harder to generate than reasons and permissions. It is controversial whether requirements to love exist at all. If they do, they are typically grounded in relational facts, like the fact that you are his mother. They are rarely if ever grounded solely in non-relational facts, like the fact that he has fantastic calves.

An analogy may help. Assume that there are several incommensurably valuable ultimate ends. We may be rationally required to adopt some of these ends, without which life may be worthless. We may be rationally required to refrain from adopting other ends that are not sufficiently worth pursuing. Yet we are seldom required to adopt particular ultimate ends. I was permitted but not required to adopt the end of becoming a philosopher, for instance. The rationalist should make parallel claims about requirements to love.

\section{Love, Emotion, Desire}

I conclude with a brief discussion of a third route to romanticism, which is an argument about love and emotion. The argument explains some of the popular appeal of romantic views, but does not explain their acceptance by philosophers. Nonetheless, its analysis can help us articulate the best underpinning for romanticism, which can be framed by way of a distinction between love and emotion that is easy to overlook. 
Here is the argument in its simplest form:

1. Emotions are not governed by reasons.

2. Love is an emotion.

3. So love is not governed by reasons.

Most philosophers rightly reject premise $1 .{ }^{68}$ Romantic views of emotion are a relic of anachronistic and artificially dichotomised conceptions of the mind. Anger, fear, sadness, and other paradigm emotions are governed by reasons. I have suggested that this is true at various points in my presentation - for example, in arguing that love is probably not especially reasons-insensitive when compared with other emotions.

Premise 2 is more controversial. Views about it cut across the rationalismromanticism divide. ${ }^{69}$ I think we should reject this premise. Love is not an emotion. $7^{\circ}$ Explaining why leads to a deflationary diagnosis about the romantic view.

Consider the following argument. $7^{1}$

1. Emotions are concern-based.

2. Love is not concern-based.

3. So love is not an emotion.

Emotions are concern-based in the sense that that they depend upon antecedent concerns. You're afraid of the coming drought because you care about devastating fires; you're angry about climate inaction because you want a healthy future for the earth. Love doesn't seem concern-based in this way. On the contrary, love appears to be, or at least to essentially involve, an intense form of concern, which is in no sense antecedent to it. It is because you love your parents

68. Pickard (2013: 1143): "Blame, like nearly all emotions, can be irrational." Compare Brogaard (2015).

69. Velleman (1999), Abramson and Leite (2011), Brogaard (2015), and Zangwill think that love is an emotion; only Zangwill is a romantic, though I have argued that Velleman is a half strength romantic. Frankfurt (2004), Naar (2013), de Sousa (2015), and Smuts (2014b) think that love is not an emotion; Naar is a rationalist, de Sousa is in my view an equivocal romantic (2015: Ch. 4), and Frankfurt and Smuts are paradigm romantics.

70. I have no account of what an emotion is. I think, with Paul Griffiths (1997), that it is a mistake to assume that the common-sense class of "emotions" is a useful, unified category. What I'll now suggest is that love is importantly different from paradigm emotions (sometimes called "basic" or "simple" emotions) - The Big Six of anger, fear, disgust, sadness, joy, and surprise. Incidentally, we should not assume, as some do (e.g., Brogaard 2015), that all of even the basic emotions will be rationally governed in the same way. To mention one obvious conundrum: it seems particularly difficult to conceptualise norms governing disgust. Still, phenomena like racialized disgust might suggest that there are some such norms.

71. Roberts (2003). See also Smuts (2014b: 511) for references to several other philosophers of emotion who accept its crucial first premise. 
that you're afraid when they encounter dangerous things, and happy when they are flourishing. Love is not an emotion, but a form of concern that disposes us to have particularly intense emotional experiences related to the object of love (Naar 2013; Shpall 2018; Smuts 2014b: 511).

What matters for present purposes is not whether this view is correct, but the fact that it is widely held. And the connection between love and concern is indeed a rare case of widespread agreement in the philosophy of love. $7^{2}$

We may now offer a natural explanation of romantic intuitions and their recalcitrance. These intuitions reproduce a popular view about the rational status of desire: Hume's view that underivative desire is not governed by reasons. My deflationary diagnosis concerning the debate about love's reasons can be stated in the following way. Romantic views are best thought of as Hume's view about desire, dressed up in fancy evening wear.

The diagnosis brings us full circle. In introducing romanticism, I noted that its most prominent contemporary defender, Harry Frankfurt, claims that love is the ground of practical reason. His motivations may not be entirely clear. ${ }^{73}$ Nonetheless, his view clearly resembles the Humean one that desire is the ground of practical reason-as I demonstrated in illustrating the familiar ways that it insulates love from rational assessment. It is not hard to see why you might endorse romanticism if you were moved by Hume's idea. As I've just argued, philosophers largely agree that love is or involves a particularly intense form of care, concern, or desire. Frankfurt himself conceives of love as a structure of the will (i.e., of desires), and readers of his work will likely find this explanatory hypothesis about its Humean foundations to be faithful, and possibly unsurprising. In sum, love seems like a prime candidate for the kind of fundamental complex of desires that sits, according to the Humean, beyond reason. ${ }^{74}$

If this diagnosis is accurate, there is no sense trying to convince romantics by appealing to arguments about love. The only way to unsettle romantic intuitions would be to directly confront Humean ideas about the rational status of under-

72. See Helm's (2010: Ch. 1) discussion of robust-concern views of love, but note that even many views that do not identify love with concern still claim that it is partially constituted by it. Ferracioli (2014: 5) regards the connection as the most uncontroversial bedrock assumption about love that she can find. Velleman (1999) is a prominent dissenter. One of his goals is to attack all conative theories of love by arguing that desires are merely commonly associated yet contingent consequences of love. I doubt he can avoid the conclusion, however: openness, receptivity, valuing of another human being (i.e., Velleman-love) necessarily involve intense concern. For something like this complaint see Abramson and Leite (2011). 307).

73. For one thing, why don't care and desire ground reasons, if love does? See Zangwill (2013:

74. Compare Grau (2010: 248). Zangwill (2013: 307) explicitly resists a metaethical foundation for romanticism, and rejects the view that love is a desire. I am not moved by his arguments here, and other romantics would reject them. See also Goldie's (2010: 65) ambivalent discussion of romanticism and what might motivate it. 
ivative desire. Metaethicists have been doing this for quite some time. It seems plausible that Hume articulated a perennial fault line in thinking about normativity. Divergent intuitions here are particularly rigid-just like the intuitions about love we've been exploring.

I end with a clarification about the explanatory ambitions of this diagnosis. At the outset I showed that romantic ideas about love have a long history, and claimed that they imbue not just our theories of love but also common behaviours and social practices. My final conjecture could only amount to a partial explanation of this complex set of facts.

Whatever explains the undeniable power of romantic ideologies, the ideas deserve our attention. They reveal a great deal about us. Philosophical critique can show us the limits of these ideas - and help us change them.

\section{References}

Abramson, Kate and Adam Leite (2011). Love as a Reactive Emotion. Philosophical Quarterly, 61(245), 673-699.

Abramson, Kate and Adam Leite (2018). Love, Value, and Reasons. In Christopher Grau and Aaron Smuts (Eds.), The Oxford Handbook of Philosophy of Love. Oxford University Press. Advance online publication. https://doi.org/10.1093/oxford$\mathrm{hb} / 9780199395729.013 .7$

Aristotle (1997). Nicomachean Ethics. Terence Irwin (Trans.). Hackett.

Austen, Jane (2001). Sense and Sensibility. The Modern Library.

Badwhar, Neera (2003). Love. In H. LaFollette (Ed.), Practical Ethics (42-69).Oxford University Press.

Brake, Elizabeth (2012). Minimizing Marriage: Marriage, Morality, and the Law. Oxford University Press.

Brogaard, Berit (2015). On Romantic Love: Simple Truths about a Complex Emotion. Oxford University Press.

Brogaard, Berit (2018). Romantic Love for a Reason. In Christopher Grau and Aaron Smuts (Eds.), The Oxford Handbook of Philosophy of Love. Oxford University Press. Advance online publication. https://doi.org/10.1093/oxfordhb/9780199395729.013.3

Brunning, Luke (2018). The Distinctiveness of Polyamory. Journal of Applied Philosophy, 35(3), 513-531.

Cocking, Dean and Jeanette Kennett (1998). Friendship and the Self. Ethics, 108(3), 502527.

D'Arms, Justin and Daniel Jacobson (2000). The Moralistic Fallacy: On the "Appropriateness" of Emotions. Philosophy and Phenomenological Research, 61(1), 65-90.

Darwall, Stephen (2017). Love's Second Personal Character: Reciprocal Holding, Beholding, and Upholding. In Esther Engels Kroeker and Katrien Schaubroeck (Eds.), Love, Reason, and Morality (93-109). Routledge.

de Sousa, Ronald (2015). Love: A Very Short Introduction. Oxford University Press.

Delaney, Neil (1996). Romantic Love and Loving Commitment: Articulating a Modern Ideal. American Philosophical Quarterly, 33(4), 339-356. 
Ferracioli, Luara (2014). The State's Duty to Ensure Children are Loved. Journal of Ethics and Social Philosophy, 8(2), 1-19.

Ferracioli, Luara (2017). Procreative Parenting, Love's Reasons and the Demands of Morality. The Philosophical Quarterly, 68(270), 77-97.

Flaubert, Gustave (1904). Madame Bovary. M. Walter Dunne (Trans.). St Dunstan Society.

Frankfurt, Harry (1999). Necessity, Volition, and Love. Cambridge University Press.

Frankfurt, Harry (2004). The Reasons of Love. Princeton University Press.

Friedman, Marilyn (1989). Feminism and Modern Friendship: Dislocating the Community. Ethics, 99(2), 275-290.

Gaita, Raymond (1998). Romulus, My Father. Text.

Goldie, Peter (2010). Love for a Reason. Emotion Review, 2(1), 61-67.

Grau, Christopher (2010). Love and History. The Southern Journal of Philosophy, 48(3), 246-271.

Griffiths, Paul (1997). What Emotions Really Are: The Problem of Psychological Categories. University of Chicago Press.

Hamlyn, David (1978). The Phenomena of Love and Hate. Philosophy, 53(203), 5-20.

Helm, Bennett (2010). Love, Friendship, and the Self. Oxford University Press.

Helm, Bennett (2017). Love. In Edward N. Zalta (Ed.), Stanford Encyclopedia of Philosophy. Retrieved from https://plato.stanford.edu/archives/fall2017/entries/love/

Hieronymi, Pamela (2005). The Wrong Kind of Reason. Journal of Philosophy, 102(9), 437547 .

hooks, bell (2000). All About Love: New Visions. Harper Perennial.

Hubin, Donald C. (1991). Irrational Desires. Philosophical Studies, 62(1), 23-44.

Hume, David (1978). A Treatise of Human Nature. P. H. Nidditch (Ed.). Oxford University Press.

Hurka, Thomas (1997). The Justification of National Partiality. In Robert McKim and Jeff McMahan (Eds.), The Morality of Nationalism (139-157). Oxford University Press.

Hurka, Thomas (2017). Love and Reasons: The Many Relationships. In Esther Engels Kroeker and Katrien Schaubroeck (Eds.), Love, Reason, and Morality (p-p). Routledge.

Jenkins, Carrie (2015). Modal Monogamy. Ergo, 2(8), 175-194.

Jenkins, Carrie (2017). What Love Is: And What It Could Be. Basic Books.

Jollimore, Troy (2011). Love's Vision. Oxford University Press.

Jollimore, Troy (2017). Love: The Vision View. In Esther Engels Kroeker and Katrien Schaubroeck (Eds.), Love, Reason, and Morality (1-19). Routledge.

Kahneman, Daniel (2011). Thinking, Fast and Slow. Penguin Books.

Keller, Simon (2001). How Do I Love Thee? Let Me Count the Properties. American Philosophical Quarterly, 37(2), 163-173.

Kolodny, Niko (2003). Love as Valuing a Relationship. Philosophical Review, 112(2), 135189.

Kraut, Robert (1987). Love De Re. Midwest Studies in Philosophy, 10, 413-430.

Kroeker, Esther Engels and Katrien Schaubroeck (Eds.) (2017). Introduction: An Overview of the Contemporary Debate on Love, Reason, and Morality. In Love, Reason, and Morality. Routledge.

Liao, Matthew (2006). "The Right of Children to be Loved." Journal of Political Philosophy, $14(4), 420-440$.

Liao, Matthew (2015). The Right to be Loved. Oxford University Press.

Little, Margaret Olivia (2013). In Defence of Non-Deontic Reasons. In David Bakhurst, 
Brad Hooker, and Margaret Olivia Little (Eds.), Thinking about Reasons: Themes from the Philosophy of Jonathan Dancy (p-p). Oxford University Press.

Maurer, Christian (2014). On 'Love at First Sight'. In Christian Maurer, Tony Milligan, and Kamila Pacovska (Eds.), Love and its Objects (160-174). Palgrave MacMillan.

McKeever, Natasha (2017). Is the Requirement of Sexual Exclusivity Consistent with Romantic Love? Journal of Applied Philosophy, 34(3), 353-369.

Murdoch, Iris (1970). The Sovereignty of Good. Routledge.

Naar, Hichem (2013) A Dispositional Theory of Love. Pacific Philosophical Quarterly, 94(3), 343-357.

Naar, Hichem (2019). The Possibility of Fitting Love: Irreplaceability and Selectivity. Synthese. https://doi.org/10.1007/s11229-018-02079-4

Nehamas, Alexander (2016). On Friendship. Basic Books.

Nozick, Robert (1989). Love's Bond. In The Examined Life: Philosophical Meditations (p-p). Simon \& Schuster.

Nussbaum, Martha (2004). "Faint with Secret Knowledge": Love and Vision in Murdoch's The Black Prince. Poetics Today, 25(4), 689-710.

Nussbaum, Martha (2016). Anger and Forgiveness. Oxford University Press.

Parfit, Derek (2011). On What Matters: Volume One. Oxford University Press.

Pettigrove, Glen (2012). Forgiveness and Love. Oxford University Press.

Pickard, Hannah (2013). Responsibility Without Blame: Philosophical Reflections on Clinical Practice. In K. W. M. Fulford, Martin Davies, Richard G. T. Gipps, George Graham, John Z. Sadler, Giovanni Stanghellini, and Tim Thornton (Eds.), The Oxford Handbook of Philosophy and Psychiatry (p-p). Oxford University Press.

Plato (1997). The Symposium. In John M. Cooper (Ed.), Plato: Complete Works (457-505). Hackett Publishing.

Protasi, Sara (2014). Loving People for Who They Are (Even When They Don't Love You Back). European Journal of Philosophy, 24(1), 214-234.

Quinn, Warren (1993). Putting Rationality in Its Place. In R. G. Frey and C. Morris (eds.), Value, Welfare, and Morality. Cambridge University Press.

Roberts, Robert C. (2003). Emotions: An Essay in Aid of Moral Psychology. Cambridge University Press.

Rorty, Amelie (1986). The Historicity of Psychological Attitudes: Love is Not Love Which Alters When It Alteration Finds. Midwest Studies in Philosophy, 10, 399-412.

Rose, Jacqueline (2018). Mothers: An Essay on Love and Cruelty. Faber and Faber.

Sabato, Ernesto (2011). The Tunnel. Penguin Classics.

Setiya, Kieran (2014). Love and the Value of a Life. Philosophical Review, 123(3), 251-280.

Shpall, Sam (2017). Love's Objects. In Esther Engels Kroeker and Katrien Schaubroeck (Eds.), Love, Reason, and Morality (p-p). Routledge.

Shpall, Sam (2018). A Tripartite Theory of Love. Journal of Ethics and Social Philosophy, $13(2), 91-124$.

Singer, Irving (1966). The Nature of Love: Volume 1. MIT Press.

Smith, Michael (2017). The "What" and "Why" of Love's Reasons. In Esther Engels Kroeker and Katrien Schaubroeck (Eds.), Love, Reason, and Morality (145-162). Routledge.

Smuts, Aaron (2014a). Is it Better to Love Better Things? In Christian Maurer, Tony Milligan, Kamila Pakovska (Eds.), Love and Its Objects: What Can We Care For? (p-p). Palgrave MacMillan. 
Smuts, Aaron (2014b). Normative Reasons for Love, Parts I and II. Philosophy Compass, 9(8), 507-526.

Srinivasan, Amia (2017). The Aptness of Anger. The Journal of Political Philosophy, 26(2), 123-144.

Srinivasan, Amia (2018). Does Anyone Have the Right to Sex? London Review of Books, $40(6)$.

Steup, Matthias (2001). Knowledge, Truth, and Duty: Essays on Epistemic Justification, Responsibility, and Virtue. Oxford University Press.

Veaux, Franklin and Eve Rickert (2014). More Than Two: A Practical Guide to Ethical Polyamory. Thorntree Press.

Velleman, David (1999). Love as a Moral Emotion. Ethics, 109(2), 338-374.

Vlastos, Gregory (1999). The Individual as an Object of Love in Plato. In Gail Fine (Ed.), Plato 2: Ethics, Politics, Religion, and the Soul (3-42). Oxford University Press.

Wolf, Susan (2010). Meaning in Life and Why It Matters. Princeton University Press.

Zangwill, Nick (2013). Love: Gloriously Amoral and Arational. Philosophical Explorations, 16(3), 298-314. 